\title{
Charlotta Forss
}

https://orcid.org/0000-0002-1548-4795

Department of History, Stockholm University

\section{KNOWLEDGE AND AGENCY. THE CASE OF CLAES RÅLAMB AND THE SWEDISH EMBASSY TO ISTANBUL, 1657-58}

\begin{abstract}
This article explores the interplay between knowledge and agency in early modern diplomacy. Focusing on the power dynamics of early modern empire through a case study of a Swedish embassy to the Ottoman Empire in 1657-58, the article shows how agency and knowledge interlinked throughout the diplomatic mission. At the centre of the study is Claes Rålamb, a Swedish nobleman who was sent to Istanbul to secure an alliance between Sweden and the Ottoman vassal state Transylvania. Rålamb's journey to, and stay in, Istanbul was framed by global political developments, yet, it was also directly influenced by local customs and personal connections. In particular, Rålamb's ability to act as an agent of the Swedish Empire was shaped by the difficulties of attaining reliable information. Moreover, the framework within which he was able to act changed between different stages of the journey. This makes the intersection between knowledge and agency a fruitful focal point for examining early modern empire, going beyond traditional national frameworks and categories of actors. Rålamb was sent out as an envoy of the Swedish empire, yet the meaning of that position changed constantly.
\end{abstract}

Keywords: History of knowledge, Ottoman Empire, Swedish Empire, agency, diplomatic persona, travel writing

The Swedish nobleman Claes Rålamb (1622-98) was an agent of the Swedish empire when, in 1657, he travelled on a diplomatic mission to the Ottoman Empire. Rålamb was sent to Istanbul to confirm an alliance 
between King Charles X of Sweden and Prince György II Rákóczi of Transylvania, who was a vassal to the Ottoman Empire. ${ }^{1}$ Sweden was at the time engaged in the Polish campaign of the Second Northern War (1655-60) and was soliciting aid from Transylvania. The position of ambassador opened doors to Rålamb and dictated his actions during the journey and in Istanbul. Rålamb's embassy is a classic case of an agent of one early modern power sent to negotiate diplomatic relations with another. However, the embassy is also a case that offers a chance to significantly complicate and deepen our understanding of what it meant in practice to be an agent of empire.

This article examines the changing nature of diplomatic agency through the case of Claes Ràlamb's embassy to the Ottoman Sultan Mehmet IV in 1657-58. Rålamb's position as ambassador and his relationship with the Swedish crown and other actors changed considerably during the journey. Significantly, Rålamb's agency as a diplomat was frequently curtailed, and the mission frustrated. In the following, I suggest that this happened at instances where Rålamb lacked the necessary and situation-specific knowledge to navigate the situation. The extensive documentation that has been preserved from the embassy give evidence of a struggle for knowledge that permeated all stages of the journey, as well as its aftermath. At some stages of the journey, this worked in Rålamb's favour; at others, it did not.

It is a given tenet of the study of diplomacy that information gathering has been central to the work of diplomats and their aids. ${ }^{2}$ In recent years, research within New Diplomatic History has brought attention to the complex way in which information gathering involves an array of actors and practices. For instance, important work has been done to highlight the role of official and unofficial intermediaries and

1 The alliance between Sweden and Transylvania was already effective when Rålamb set out for Istanbul. Swedish and Transylvanian envoys were sent to Istanbul to garner Ottoman sanction of the alliance because Transylvania was not an independent state. See Gábor Kárman, Confession and Politics in the Principality of Transylvania 1644-1657 (Göttingen: Vandenhoeck \& Ruprecht, 2020), chapter 9.

2 Noé Cornago, 'Diplomatic knowledge', in The SAGE handbook in diplomacy, ed. by Costas M. Constantinou, Pauline Kerr, and Paul Sharp (London: SAGE Publications Ltd., 2016). 
showcase the importance of archival practices as part of early modern diplomacy. ${ }^{3}$ The limits and frustrations of the diplomatic agency are also significant for this actor-centred approach. To highlight this aspect, recent work within the history of knowledge can provide a useful perspective. Rather than focusing primarily on agency, this field has emerged to historically contextualise the making and validation of different forms of knowledge. ${ }^{4}$ In the present study, I bring conceptual tools developed by historians of knowledge to bear on the case of Claes Rålamb's embassy. In particular, the history of knowledge provides important insights through its attention to how the making and circulation of knowledge are often filled with friction. ${ }^{5}$ As noted by Lukas M. Verburgt, 'failure is inherent to knowledge production'. ${ }^{6}$ The case of Claes Rålamb's embassy offers a chance to examine this statement concerning diplomatic agency. Beyond the specific case study, this essay is an argument for how the history of knowledge and diplomatic history can inform each other.

The Rålamb embassy was, in the long run, not a success in terms of political gains. ${ }^{7}$ However, it has left a wealth of documentation that

${ }^{3}$ Jan Hennings, 'Information and Confusion: Russian Resident Diplomacy and Peter A. Tolstoi's Arrival in the Ottoman Empire (1702-1703)', International History Review, 41, no. 5 (2019), 1-17; Filippo de Vivo, 'Archives of Speech: Recording Diplomatic Negotiation in Late Medieval and Early Modern Italy', European History Quarterly, 46, no. 3 (2016), 519-44; E. Natalie Rothman, Brokering Empire: TransImperial Subjects between Venice and Istanbul (Ithaca: Cornell University Press, 2011).

${ }^{4}$ See Circulation of Knowledge: Explorations in the History of Knowledge, ed. by Johan Östling, Erling Sandmo, David Larsson Heidenblad, Anna Nilsson Hammar, and Kari Nordberg (Lund: Nordic Academic Press, 2018); Kapil Raj, Relocating Modern Science: Circulation and the Construction of Knowledge in South Asia and Europe, 1650-1900 (New York: Palgrave Macmillan, 2007); James A. Secord, 'Knowledge in Transit', Isis, 95, no. 4 (2004), 654-67. Naturally, there are also historians of knowledge who take actor-centred approaches, not least Steven Shapin and Simon Schaffer, Leviathan and the Air-Pump: Hobbes, Boyle, and the Experimental Life (Princeton: Princeton University Press, 1985).

5 The dark side of knowledge: histories of ignorance, 1400 to 1800, ed. by Cornel Zwierlein (Leiden: Brill, 2016); Agnotology: The Making and Unmaking of Ignorance, ed. by Robert Proctor and Londa Schiebinger (Stanford: Stanford University Press, 2008).

${ }^{6}$ Lukas M. Verburgt, 'The history of knowledge and the future history of ignorance', KNOW, 4 (2020), 1-24 (p. 7).

7 Björn Asker, 'Clas Rålamb', Svenskt biografiskt lexikon, https://sok.riksarkivet.se/ Sbl/Start.aspx (accessed 13 March 2021); The Sultan's Procession: The Swedish Embassy 
has caught the interest of generations of historians. Rålamb penned a diary and handed in a formal report to the Swedish authorities, as did his secretary Jonas Kling (ennobled Klingstedt). ${ }^{8}$ The German priest Conrad Jacob Hiltebrandt, who accompanied a second envoy sent by Charles X to Istanbul, likewise wrote an account of the embassy, and the secretary Johann Ulrich Wallich published a treatise on Islam after returning from Istanbul. ${ }^{9}$ Twenty years after the embassy, Rålamb published his account, with an introduction that noted that his journal had circulated widely in manuscript and that Rålamb wished for an authoritative version to be disseminated. ${ }^{10}$ The expenditures can be followed through the accountant Olof Hansson's notes. ${ }^{11}$ In addition, Rålamb's notes, drawings, and paintings that he brought from Istanbul give additional evidence of information gathering strategies. ${ }^{12}$

These detailed accounts give complementary perspectives on the embassy and provide an opportunity to compare the retelling of events between different viewpoints and for different audiences. In earlier research, the material has been used extensively to discuss Ottoman-Swedish relations and investigate images of the 'Other' in seventeenth-century

to Sultan Mehmed IV in 1657-1658, ed. by Karin Ådahl (Istanbul: Swedish Research Institute in Istanbul, 2006), p. 18.

${ }^{8}$ Claes Rålamb, Diarium under resa till Konstantinopel 1657-1658, ed. by Christian Callmeri, Historiska Handlingar Series, 37:3 (Stockholm: Kungl. Samfundet för utgifvande af handskrifter rörande Skandinaviens historia, 1963); Riksarkivet, Stockholm (hereafter cited as RA), Turcica I, vol. 3, Claes Rålamb, Kortt Berättelse Om det som wid den Constantinopolitaniske resan är förelippit; Uppsala University Library, N 439, Jonas Kling, Hans Kongl Majtts Ablegation till Turkiske hofwet uthi een summa föfattat; Kungliga biblioteket, Stockholm hereafter cited as KB), Jonas Kling, Diarium på bestickningen till Konstantinopel, 1657-58, Rål. 4:o 25.

9 Johann Ulrich Wallich, Religio Turcica (Stade: Typis Holvinianis, 1659); Conrad Jacob Hiltebrandt's Dreifache Schwedische Gesandtschaftsreise nach Siebenbürgen, der Ukraine und Constantinopel (1656-1658), ed. by Franz Babinger (Leiden: Brill, 1937).

${ }^{10}$ Claes Rålamb, Kort beskriffning om thet som wid then Constantinopolitaniske resan är forreluppit (Stockholm, 1679), p. 2, English translation: Nicholas [sic] Rålamb, 'A relation of a journey to Constantinople', in A Collection of Voyages and Travels, Some Now First Printed from Original Manuscripts, others Now First Published in English (London, 1732), vol. 5, pp. 669-716.

${ }^{11}$ KB, Cod. Holm. Rål., Olof Hansson, Olof Hanssons kassabok, fol. 135.

12 Nordiska Museet, Stockholm, Granhammarsamlingen, Claes Rålambs ambassad till Höga porten; KB Rål. 8:o 10, Turkiska klädedrägter. 
Sweden. ${ }^{13}$ The visual material has also been discussed as an example of cultural exchange between Europe and the Middle East in the early modern period. ${ }^{14}$ Placing the accounts in a broader context of European political history, Gábor Kármán has contextualised the Rålamb embassy in relation to political developments in Central Europe. ${ }^{15}$ In different ways, earlier research has done much to enhance our understanding of the significance of the Rålamb embassy in terms of political history and cross-cultural interactions. Building on this work, the present study uses the accounts as a case study to explore agency and the role of fraught knowledge in early modern diplomacy.

Of particular relevance for the present study, literary scholar Carina Lidström analyses roles, or persona, that Rålamb and other Swedish early modern travel writers used as part of their narratives. ${ }^{16}$ Lidström understands persona as a literary device used to portray specific ideas to the readers of an account. She argues that in the printed version of his account, Rålamb presented himself as a hero and a loyal servant to the king. ${ }^{17}$ In the present study, I take a slightly different approach to the concept of persona, using it to analyse what conceptions Rålamb had of the role of the diplomat: what knowledge he had of the diplomatic persona. In other words, while Lidström focuses on the literary persona Rålamb presented in his account, this study explores what his account can tell us of how he conceptualised the diplomatic persona. This role

13 Gábor Kármán, 'Främlingskapets grader: Claes Rålambs resa till Osmanska riket 1657-1658', Karolinska förbundets årsbok (2008), 40-107; Göran Larsson, 'En svensk 1600-talsbeskrivning från den Stora Porten i öster', Folkets historia, 27, no. 2 (1999), 2-12; Bernt Brendemoen, 'Some Remarks on Claes Brodersson Rålamb and his contemporaries', in Turcica et Orientalia, vol. 1: Studies in honour of Gunnar Jarring on his eightieth birthday 12 October 1987 (Stockholm: Swedish Research Institute in İstanbul, 1988), pp. 9-18; Främlingar: Ett historiskt perspektiv, ed. by Anders Florén and Åsa Karlsson (Uppsala: Historiska institutionen, Uppsala Univiversitet, 1998).

14 Sultan's Procession.

15 See for example Gábor Kármán, 'The networks of a Wallachian pretender in Constantinople: the contacts of the future voivode Mihail Radu 1654-1657', in Europe and the 'Ottoman World': Exchanges and Conflicts (Sixteenth to Seventeenth Centuries), ed. by Gábor Kármán and Radu G. Paun (Istanbul: The Isis Press, 2013).

16 Carina Lidström, Berättare på resa: Svenska resenärers reseberättelser 1667-1829 (Stockholm: Carlssons förlag, 2015).

${ }^{17}$ Ibid., pp. 103-11. 
was performed in specific situations during the mission and in his accounts reporting on the journey after its completion.

The sequence of events that made up Rålamb's embassy to the Ottoman Empire and his eight-month-long stay in Istanbul can be presented in several different ways. In the end, Sultan Mehmed IV opposed Prince Rákóczi's alliance with Sweden, and Rákóczi's initiative was seen as insubordination and cost him his title. ${ }^{18}$ Meanwhile, the Swedish war efforts shifted from Poland to Denmark, making the alliance less of a priority from a Swedish perspective. Simultaneously, the Ottomans were in conflict with Venice and did not focus on the Baltic affairs. ${ }^{19}$ Seen in this light, Rålamb's embassy was an attempt that, in the end, did not materialise because the political and military situation made it less relevant.

Another way to look at the episode is to use the approach of New Diplomatic History and focus on the individuals involved in the enterprise. ${ }^{20}$ This study uses this second perspective, with one significant caveat. Focusing on individuals often means attributing agency and significance to the actions of individual persons. One reason for this is that researchers (and publishers, together with the reading public) are drawn to success stories. It is much easier to sell a book about a person who made a difference than about someone who did not. This, however, is a problem from the point of view of research, since many individuals did not change history, yet, their biographies can contribute in crucial ways to our understanding of the past. ${ }^{21} \mathrm{~A}$ focus on agency can, thus, obscure the complex nature of early modern diplomacy. While Rålamb and his aids did not lack agency altogether - on the contrary, it is clear that they acted and influenced events - the mission was ultimately not a success in terms of political gains. This makes the Rålamb’s

18 Özgür Kolçak, 'A Transylvanian ruler in the talons of the "hawks": György Rákóczi II and Köprülü Mehmed Pasha', in Turkey \& Romania: A History of Partnership and Collaboration in the Balkans, ed. by Florentina Nitu et al. (Istanbul: Union of Turkish World Municipalities, 2016).

19 Sultan's Procession.

${ }^{20}$ Jan Hennings and Tracey Sowerby, 'Introduction', in Practices of Diplomacy in the Early Modern World c. 1410-1800, ed. by Jan Hennings and Tracey Sowerby (London: Routledge, 2017), p. 3.

${ }^{21}$ For a parallel discussion, see Kaarle Wirta, Early Modern Overseas Trade and Entrepreneurship (London: Routledge, 2020). 
embassy a fruitful case for exploring the complex nature of diplomatic agency, and for interpreting it as a struggle for knowledge.

\section{TRAVELLING INCOGNITO}

To begin with, Claes Rålamb's embassy in Istanbul gives insight into how diplomats were expected to appear and act, and how a knowledge of this could be subverted. As noted by scholars working on performativity and the embodiment of knowledge, appearance was important for manifesting status and upholding social norms in early modern Europe. ${ }^{22}$ The diplomatic envoy was no exception; he - and it was generally a he - was expected to appear and behave according to a common understanding of what we might call a diplomatic persona. ${ }^{23}$ What this persona entailed changed between places and over time. However, a knowledge of the diplomatic protocol, what was expected in terms of appearance and behaviour, was crucial. ${ }^{24}$ Ràlamb's case is an example of how this knowledge could be used to one's advantage.

The first problem that faced Claes Rålamb when he set out on his embassy was how to get to Istanbul. The Swedish authorities applied to the Holy Roman Empire to get a passport for their envoy, but the application was denied - twice. Instead, it was decided that the most expedient solution would be for Rålamb to travel incognito. ${ }^{25}$ For the

22 Astrid Pajur, Dress Matters: Clothes and Social Order in Tallinn, 1600-1700 (Uppsala: Acta Universitatis Upsaliensis, 2020); Performing Herself: Everyday Practices and the Making of Gender in Early Modern Sweden, ed. by Mikael Alm (Uppsala: Uppsala University, 2017); Ulinka Rublack, Dressing Up: Cultural Identity in Renaissance Europe (Oxford: Oxford University Press, 2010).

23 On the performative aspect of Ottoman diplomacy, see Michael Talbot, British-Ottoman Relations, 1661-1807: Commerce and Diplomatic Practice in Eighteenth-Century Istanbul (Woodbridge: The Boydell Press, 2017), chapter 5.

${ }^{24}$ Mahmut Halef Cevrioğlu, 'Grand vizierial reception ceremonies of European ambassadors in the first half of the seventeenth century', Legatio, 4 (2020), 123-41; Christine Vogel, 'The Caftan and the Sword: Dress and Diplomacy in Ottoman-French Relations Around 1700', in Fashioning the Self in Transcultural Settings: The Uses and Significance of Dress in Self-Narratives, ed. by Claudia Ulbrich and Richard Wittmann (Würzburg: Ergon Verlag, 2015).

25 Rålamb, Diarium, pp. 34-37; Kling, Hans Kongl Majtts Ablegation, fol. 140r; Rålamb, Kort beskriffning, p. 6. 
first stage of the journey, then, Rålamb could not use his status as an envoy of the Swedish empire. On the contrary, he tried hard to keep the knowledge of his identity hidden.

Primarily, Rålamb used disguises to hide who he was. In his travel journal, he describes the different modes of disguise that he applied, including using false passports of 'sometimes an officer, sometimes a student, sometimes a merchant', wearing disguises like a 'black-brown wig' or 'unkempt dress', or being dressed like a merchant, using a false name or speaking foreign languages. ${ }^{26}$ On a couple of occasions, he took the role of specific persons, such as pretending to be the stable master of Sten Bielke, the Swedish envoy to the elector of Saxony. ${ }^{27}$

These different modes of disguise highlight how appearing as a diplomatic envoy was not only a question of carrying instructions for a diplomatic mission. Instead, the diplomat was recognised through dress and bearing, performing his role through all facets of his appearance. By subverting the expected appearance of a Swedish envoy, Rålamb could travel incognito. This is one instance where he used the established knowledge of European diplomacy to the advantage of the Swedish cause. ${ }^{28}$

On the way to Istanbul, Rålamb also used knowledge of everyday sociability to divert attention away from himself. In Wittenberg, a common destination for complementary studies for Swedish students in the sixteenth and seventeenth centuries, Rålamb found himself having dinner at the same inn as a group of young noblemen from Sweden and Holstein. Clearly, there was a risk that Rålamb and his fellow travellers would be recognised. Indeed, it turned out that Rålamb's accountant Olof Hansson had studied with one of the Swedish students in Uppsala. As a result, Hansson had to leave the room so as not to be recognised. Rålamb and his secretary Jonas Kling switched to speaking French and German so as not to be suspected of being Swedish.

26 'stundom som en Officerare stundom som en Student, Kiöpman etc.', 'en swartbrun Peruqve', Rålamb, Diarium, pp. 36, 39. See also, Rålamb, Kort beskriffning, p. 7.

27 Rålamb, Diarium, p. 47.

28 Rålamb and his entourage also used dress to hide who they were in Istanbul, see: Kling, Diarium, fol. $7 \mathrm{v}$. 
Rålamb wrote in his journal that the students were 'seeking news of the affairs between Sweden and Denmark which then were on the brink of rupture'. ${ }^{29}$ To deter suspicions, Rålamb spoke about recent affairs between Sweden and Denmark as if he had been from Hamburg, and thereby hoped to create a rift between the students. The result was that the students started fighting among themselves and forgot to ask more about Rålamb's group.

This episode might not have happened as Rålamb describes it. The printed account of the journey presented the episode in a different light. Here, Rålamb simply noted that the students 'did not recognise me because I had disguised myself with a black-brown wig'. ${ }^{30}$ As the printed account was published twenty years after the actual journey, the discrepancy might simply result from a faulty memory, or Rålamb might have decided to save space by condensing the narrative. Both versions, though, portray Rålamb as crafty, and, as noted by Lidström, this was most likely the main reason he included them. ${ }^{31}$ The case is also interesting in shedding light on a situation that the author presented as conceivable. As such, it is an example of how political conflicts were understood to play out in everyday situations: a group of people from different places ate and talked about ongoing political developments, yet, this also brought out the differences between them and ended the evening in conflict. ${ }^{32}$

In Wittenberg and elsewhere along the road to Istanbul, Rålamb used misinformation to his benefit. He made good use of his various physical disguises and used the information to mislead and hide his true identity. In sum, he subverted the expected behaviour and appearance of a diplomatic envoy to his gains. Rålamb was an agent of empire, yet, travelling to Istanbul, the effectiveness of the mission depended on knowing how to break with the diplomatic persona.

29 'sökte effterrättelse om Conjuncteuren emellan Swerige och Danmarck som då stod på Spettzen af ruptur', Rålamb, Diarium, p. 38.

30 'kände migh intet igen effter iagh hade dequserat migh med en swartbrun Peruque', Rålamb, Kort beskriffning, p. 7.

31 Lidström, Berättare på resa, p. 110.

32 For a discussion of sociability and the practice of drinking together, see Phil Withington, 'Company and sociability in early modern England', Social History, 32, no. 3 (2007), 291-307. 


\section{A LACK OF KNOWLEDGE}

While Rålamb seems to have been - or at least could portray himself as skilled in performing and manipulating the appearance of the expected diplomatic persona while travelling through Central Europe, he had more trouble navigating the Ottoman court and the diplomatic community in Istanbul. To some extent, this was the result of unfavourable political circumstances. However, I would like to suggest that, equally important, was the fact that Rålamb and his entourage came relatively unprepared for their mission, lacking knowledge of both Ottoman affairs and the local diplomatic protocol. This is particularly interesting to consider in light of the attention New Diplomatic History has paid to court ceremonials as a constitutive part of the diplomatic practice. ${ }^{33}$ Rålamb's ignorance of the diplomatic protocol clearly hindered his effectiveness as an agent for the Swedish Empire and made information gathering even more of prime concern.

Because Rålamb travelled incognito to Istanbul, he could not bring diplomatic gifts. This is the first instance in a series of mishaps that gave the Swedish envoy a disadvantaged position for negotiation - on top of the already precarious political situation. ${ }^{34}$ Like the protocol of many other early modern courts, the Ottoman court protocol included the exchange of gifts. The ceremonials that made up the reception of a new diplomat in Istanbul was crucial for establishing a good relationship. ${ }^{35}$ Indeed, such ceremonials were central for the Ottoman diplomatic practice that centred on establishing notions of friendship. ${ }^{36}$ The year before, the French envoy Jean de la Haye had omitted giving gifts, and Clarence Dana Rouillard comments that this decreased his standing significantly. ${ }^{37}$ Charles $\mathrm{X}$ had decided to prioritise getting Rålamb

33 Practices of Diplomacy; Giora Sternberg, 'Epistolary ceremonial: corresponding status at the time of Louis XIV', Past and Present, 204 (2009), 33-88.

34 Sultan's Procession, p. 12.

35 Talbot, British-Ottoman Relations; Cevrioğlu, 'Grand vizierial reception'.

36 Güneş Işılksel, 'Hierarchy and Friendship: Ottoman Practices of Diplomatic Culture and Communication (1290s-1600)', Medieval History Journal, 22, no. 2 (2019), pp. 1-20.

37 Clarence Dana Rouillard, The Turk in French History, Thought, and Literature (1520-1660), Etudes de Litterature Etrangere et compare Series, no. 13 (Paris: Boivin \& Cie, 1940), p. 154. 
quickly to Istanbul. As a result, the first communication Rålamb had with the Grand Vizier was to make excuses for his breach in protocol. ${ }^{38}$

The Swedish position was weakened further when the Swedish king sent a second envoy, the German Gotthard Welling, to reiterate Rålamb's message. ${ }^{39}$ Rallamb complained in his journal that this move had undermined his position. ${ }^{40}$ Earlier research has also noted that the Ottoman officials believed Rålamb had fallen out of favour with the king and that the Ottomans had difficulties interpreting the relationship between Rålamb, who, as a Swedish nobleman, had a higher social status, and Welling, who had been given his instructions most recently. ${ }^{41}$

These breaches in protocol beg the question of what understanding the Swedish administration had of Ottoman diplomacy and what prior knowledge a diplomat like Rålamb was expected to have when embarking on a diplomatic mission. In relation to Christian countries closer at hand, the Ottoman Empire was often portrayed as the 'Other' by early modern European scholars and travellers. ${ }^{42}$ Still, general knowledge of Ottoman affairs was available to the mid-seventeenth-century Swedish elite, and some had a deeper understanding. ${ }^{43}$ Nevertheless, Rålamb and his aides were probably not chosen for this mission because of any previous exposure to the Ottoman Empire. It is difficult to know what motivated the specific assignment, yet, no member of the group is known to have been knowledgeable in Ottoman affairs prior to the mission.

38 Rålamb, Diarium, p. 97; Rålamb, Kort beskriffning, p. 17.

39 Welling had previously acted as a Swedish envoy to Transylvania. See Kárman, Confession and Politics, p. 201.

40 Rålamb, Diarium, p. 119.

41 Sultan's Procession, pp. 16-17; However, Callmer notes that more important was the de facto alliance between Sweden and Transylvania. Callmer, p. 119, fn. 59.

42 Charlotta Forss, The Old, the New and the Unknown: The Continents and the Making of Geographical Knowledge in Seventeenth-Century Sweden (Turku: Iloinen tiede, 2018); Nancy Bisaha, Creating East and West: Renaissance Humanists and the Ottoman Turks (Philadelphia: University of Pennsylvania Press, 2004); Denys Hay, Europe: The Emergence of an Idea (Edinburgh: Harper Torchbooks, 1966).

43 Göran Bäärnhielm, 'Orientalistiken i Sverige fram till 1720-talet', in En resenär i svenska stormaktstidens språklandskap: Gustaf Peringer Lillieblad (1651-1710), ed. by Éva Á. Csató, Gren-Eklund Gunilla, and Folke Sandgren (Uppsala: Acta Universitatis Upsaliensis, 2007); Åsa Karlsson, 'Främling eller vän? Svenskar i Turkiet på 1700-talet', in Främlingar, pp. 73-87. 
Rather than being appointed because of subject expertise or experience, it seems that a combination of practicality and a record of competence recommend Rålamb to the post. Sten Westerberg notes that Rålamb, although only thirty years old, had a record of being able to execute challenging tasks well. ${ }^{44}$ Rålamb had some prior diplomatic experience, having taken part in the peace negotiations between Denmark and Sweden at Brömsebro in 1645 . He had also attended the peace conference in Osnabrück that concluded the Thirty Years' War as a young man returning from his European grand tour. ${ }^{45}$ To this reputation of competence should be added that Rålamb was close at hand when the mission was planned, being posted in Posen in Poland and already involved in the Polish campaign of the Second Northern War. ${ }^{46}$

Building networks of competent diplomats and intermediaries was a goal for European states. ${ }^{47}$ However, Rålamb was not singular in lacking knowledge about the part of the world he was sent to. Simon Reniger von Reningen, the contemporaneous ambassador of the Holy Roman Empire, came equally unprepared to Istanbul. Zsuzsanna Cziráki has shown that when deciding to send Reniger von Reningen to Istanbul, his loyalty to the emperor, familiarity with international law, and good health were more important than expertise in Ottoman affairs. ${ }^{48}$ In contrast to Reniger von Reningen, though, Rålamb and his superiors could, most likely, not read up on the intelligence collected by earlier diplomats before planning the mission. When Rålamb was

44 Sten Westerberg, 'Claes Rålamb: Statesman, scholar and ambassador', in Sultan's Procession, pp. 32-33.

45 Asker, 'Clas Rålamb'.

46 Westerberg, 'Claes Rålamb', pp. 32-33.

47 Zsuzsanna Cziráki, 'Language students and interpreters at the mid-seventeenth-century Habsburg embassy in Constantinopel', Theatrum Historiae, 19 (2016), 27-44; Emrah Safa Gürkan, 'Mediating boundaries: Mediterranean go-betweens and cross-confessional diplomacy in Constantinople, 1650-1600', Journal of Early Modern History, 19, nos. 2-3 (2015), 107-28; E. Natalie Rothman, 'Interpreting dragomans: boundaries and crossings in the early modern Mediterranean', Comparative Studies in Society and History, 51, no. 4 (2009), 771-800.

48 Zsuzsanna Cziráki, 'Making decisions at the imperial court in Vienna related to the election procedure of the resident ambassador Simon Reniger von Renningen (1649-1666) in Constantinople', Archivum Ottomanicum, 33 (2016), 91-98 (p. 97). 
sent to Istanbul, he was preceded only by a couple of official Swedish envoys. ${ }^{49}$ And, because Rålamb himself (as well as the Swedish king and his administration) was not anywhere near Stockholm when the mission was initiated, it is unlikely that Ralamb saw the accounts of his predecessors before the mission. ${ }^{50} \mathrm{He}$ discussed the mission and strategy with representatives from Transylvania that he visited on the road to Istanbul, yet, at that point, the choice to travel without gifts was already made. ${ }^{51}$ These circumstances, paired with a precarious political position, seems to have made Rålamb's task decidedly more difficult.

\section{A PRECARIOUS BALANCE}

Information gathering is a crucial aspect of any diplomatic mission, and the central role of intermediaries for transmitting information in early modern diplomacy has been discussed extensively by earlier research. ${ }^{52}$ As noted by Emrah Safa Gürkan, intermediaries were crucial in early modern Istanbul since both Ottoman officials and European diplomats tended to lack appropriate training for cross-cultural communication. ${ }^{53}$ As seen, Rålamb and his entourage was no exception in this regard. Likely due to his lack of knowledge of Ottoman affairs, Rålamb constantly sought - and relied heavily on - intermediaries and the other envoys

49 See RA, Turcica I; On the status of these envoys, see: Elżbieta Święcicka, 'Ottoman manuscripts in Europe: the collection of Ottoman-Turkish documents in Sweden', in Frontiers of Ottoman Studies: State, Province, and the West, ed. by Colin Imber, Keiko Kiyotaki, and Rhodas Murphey (London: I.B. Tauris, 2005), vol. 2, p. 50; Kaj M. Ettlinger, 'Aslan Aga - turkisk ambassadör till Sverige eller svenskt sändebud med diplomatiska uppdrag till Turkiet?', Personhistorisk tidskrift, 94 (1998), 3-19; Elżbieta Święcicka, 'Den diplomatiska trafiken mellan Sverige, Tatariet och Osmanska riket från Gustav Vasas tid till Karl XII', in Den nordiska mosaiken: Språk- och kulturmöten i gammal tid och i våra dagar, humanistdagarna vid Uppsala universitet 1997, ed. by Rut Boström Andersson (Uppsala, 1997), pp. 291-305.

50 Indeed, Rålamb's 1679 printed account of the embassy included sections copied from the envoy Paul Strassburg who had been in Istanbul in 1634, while the earlier journal did not. On the information flow between Russian diplomats, see Hennings, 'Information and Confusion'.

51 Rålamb, Diarium, p. 70.

52 For example, Rothman, Brokering Empire.

53 Gürkan, 'Mediating boundaries', p. 111. 
in Istanbul for information about what was going on at the Ottoman court. ${ }^{54}$ The Swedish legation sought information about everything from important political developments to the minutiae of court protocol. ${ }^{55}$ For instance, Secretary Kling - who, as mentioned, could speak French - was sent to the French resident Jean de la Haye ahead of the first audience with Sultan Mehmet IV to enquire into the customs for presenting documents. As a result of these inquiries, the Swedes bought blue silk and let it be sewn into a bag to carry Rålamb's credentials in, as was the custom at the High Porte. ${ }^{56}$ Through Istanbul-based middlemen such as the Polish-Ottoman Wojciech Bobowski/Ali Ufki Bey, the Swedes tapped into a broad information network, gaining information about religious affairs, Ottoman rules of sociability, and recent political news. ${ }^{57}$

When seeking out information, Rålamb was struggling to balance the need for information with upholding the diplomatic protocol. As seen, proper conduct was necessary. Thus, in addition to making sure he had the correct attire for the audience with the sultan, Rålamb wrote to various people to learn about issues like how to enter Istanbul correctly and how to time responses to the Ottoman officials. ${ }^{58}$ At the same time, Rålamb and the other diplomats repeatedly and knowingly transgressed the Ottoman regulations.

One instance that showcases this balance was the question of receiving visitors. The Ottoman protocol dictated that foreign diplomats should have their audiences with the Grand Vizier and the Sultan before seeing any other diplomats. ${ }^{59}$ Still, Rålamb noted in his diary that as soon as he had settled in his lodgings in Istanbul, he received representatives from the French resident Jean de la Haye and the English resident Thomas

54 References to information from the other European diplomats abound in the accounts. See, for example, Kling, Hans Kongl Majtts Ablegation, fol. 140r; Kling, Diarium, fols 33r, 50r; See also Kármán, 'The networks of a Wallachian pretender', pp. 133-34.

55 For example: Kling, Hans Kongl Majtts Ablegation, fols 147v-50v; Kling, Diarium, fols 13r, 20r, 21v, 55v.

56 Rålamb, Diarium, pp. 103-04.

57 See for example, Rålamb, Diarium, pp. 168, 175; Sultan's Procession, p. 16; Kármán, 'The networks of a Wallachian pretender', p. 133.

58 Rålamb, Kort beskriffning, pp. 27-28.

59 Hennings, 'Information and Confusion', p. 8. 
Bendish. ${ }^{60}$ Simon Reniger von Reningen, the ambassador of the Holy Roman Emperor, also sent one of his underlings to greet Rålamb on that first day. However, the Ottoman assigned messenger, Ali Ağa, turned him away because Rålamb had not established proper relations with the Ottomans. Rålamb got upset, and bristled to Ali Ağa that 'it was a common courtesy among the Christians to send and greet each other, and nothing of importance was discussed, and anyway these crowns were in such a way with each other connected, that what one did, was as if all made it'. ${ }^{61}$ Rålamb also made sure to send a messenger in return to Reniger von Reningen and explain that it was not he, but his hosts, who had denied entrance. Here, we see Rålamb trying to avoid offending the other envoys and to appear in control in relation to local authorities. In reality, he was very much dependent on the goodwill of both his fellow diplomats and of the Ottomans, as was clearly demonstrated when he lost the favour of the latter.

Rålamb seems to have been eager to speed up the negotiations in Istanbul but was cautioned to be patient by the English envoy and by his acquaintance, Melek Ahmed Paşa, the governor of Silistria. ${ }^{62}$ Rålamb did not heed this advice, and, as a result, he was told off by Ottoman officials. Similarly, he tried to visit Thomas Bendish without permission and was again told off. ${ }^{63}$ The notes of Secretary Kling showcase an increasing frustration on the part of the Swedish party. Early on in the stay, Kling wrote that ' 19 August came the English ambassador here for the sake that we had asked of him, and after dinner he sent his secretary to us, to notify us, that he was warned by a Turk, who was his good friend, that he should not for a few days ask for an audience or touch our case' ${ }^{64} \mathrm{~A}$ month later, the negotiations were still progressing slowly

${ }^{60}$ On Thomas Bendish, see: Jason Cameron White, 'Royal authority versus corporate sovereignty: the Levant Company and the ambiguities of early Stuart statecraft', Seventeenth Century, 32, no. 3 (2017), 231-55; Daniel Goffman, Britons in the Ottoman Empire, 1642-1660 (Seattle-London: University of Washington Press, 1998).

${ }^{61}$ Rålamb, Diarium, p. 99.

${ }^{62}$ For example, see ibid., pp. 148, 151, 155.

63 Ibid., p. 117.

64 'den 19/29 aug kom Engelske Ambassadeuren hit till den ände som wij aff honom begärat hade, och skickade efter middagen sin secreterare till oss, att notifiera 
and Kling, with a troubled air, noted that ' 18 September neither did our çavuş [messenger] come back [today] as he had promised, which gave us further worries' ${ }^{65}$ In both these passages, we see multi-layered sources for information. Not only the English envoy, but his connections - described as a 'friend' - were essential for gathering information. It is also clear that the standing of the Swedish embassy was becoming precarious.

This was in part collateral of the fraught relations between Sultan Mehmet IV and his vassal Rákóczi. ${ }^{66}$ At the low point of relations between the Swedes and their hosts, Kling wrote in his diary that 'There was a rumour in the city that we were imprisoned or would be presently'. ${ }^{67}$ Considering the experiences of the other envoys in Istanbul at the time, this worry does indeed seem well-founded. As noted by Güneş Işıksel, the Ottoman perspective was that foreign diplomatic envoys could be personally reprimanded on account of what the states they represented did. ${ }^{68}$ Thus, the Transylvanian envoy was put in prison because of Rákóczi's attempted alliance with Sweden. The French envoy and his son ended up in prison only a year after, and likewise, the English ambassador had been imprisoned in $1651 .^{69}$

Maintaining friendly relations and acquiring knowledge were closely interrelated, but these goals were not always compatible. For diplomacy to be effective, information gathering was crucial, and perhaps especially if a diplomat arrived without much prior knowledge of the court or society he was visiting. For Rålamb, the result was a balancing act where his ability to act was tied up with an often precarious struggle for knowledge.

oss, att han war warnat aff en Turk, som war hans godhe wän, att han ännu på några dagar intet skulle begiära audience, och röra om wår saak', Kling, Diarium, fol. 21v.

65 'intet heller kom wår Chiaux tillbaka, som han lofwadhe hwilket gaff oss åter griller i hufwudet', Kling, Diarium, fol. 30r.

66 See Kling, Diarium, fols 13v-14r.

67 'gick ett ryckte kring hela stadhen att wij och wore fängslade, eller och med dett förste skulle blifwa', Kling, Diarium, fols 13v-14r.

68 Güneş Işıksel, 'Ottoman Diplomacy', in The Encyclopedia of Diplomacy, ed. by Gordon Martel (Chichester: John Wiley \& Sons, 2018), p. 7.

69 On de la Haye, see Mary Hossain, 'The employment and training of interpreters in Arabic and Turkish under Louis XIV: France', Seventeenth-Century French Studies, 14, no. 1 (1992), 235-46 (p. 235). On Bendish, see Liane Saunders, 'Bendish', in Oxford Dictionary of National Biography, https://www.oxforddnb.com (accessed 5 June 2021). 
A study of diplomacy can bring essential insights to the history of knowledge in this regard. Not knowing was not simply an absence of knowledge but could be a real and tangible security risk that curtailed effective action.

Moreover, the balancing act that the Swedes were engaged in had a third component. Not only did they have to balance the risk of worsening relations with the possibility of gaining valuable information; in their accounts, they were also writing for an audience back in Sweden and, more specifically, to the Swedish king. Rålamb was careful to present himself as resourceful and his failures as dependent on external factors rather than personal shortcomings. As noted by Dariusz Kołodziejczyk in relation to early modern Polish envoys to Istanbul, the reports of unfavourable events were likely modified to save face. ${ }^{70}$ Thus, when Rålamb described how he took risks and defied Ottoman protocol, he was likely trying to spin the narrative to appear in control of a rapidly deteriorating situation. Coming home from an extended stay in Istanbul without any real political gains, it is not surprising that Rålamb wished to portray his actions in the best possible light.

\section{THE PRICE OF KNOWLEDGE}

The documentation from the Rålamb embassy gives interesting opportunities to study in detail how different motivations for providing information could play out. While some of the contacts shared political goals with the Swedish legation, there were also more complex motivations for providing information and deciding not to share.

One motivating factor for exchanging information from the perspective of intermediaries was the possibility of earning money. In the documentation from the Ralamb embassy, this is evidenced by sums being paid to, for instance, 'A Turk who carried new news' and 'a Jew who carried a letter from the King..$^{71}$ Sometimes, the diplomatic relations overlapped with the day-to-day practicalities of the embassy, such as

70 Dariusz Kołodziejczyk, 'Semiotics of behavior in early modern diplomacy: Polish embassies in Istanbul and Bahçesaray', Journal of Early Modern History, 7, nos. 3-4 (2003), 245-56 (p. 253).

71 'en Turk som bar nija tiender', 'en Jude som bar breff ifrpn Kongen', Hansson, Olof Hanssons kassabok, fols 23r, 28r. 
when the accountant Olof Hansson notes that he had paid 'The servant of the Englishman, who brought beer to the master' ${ }^{72}$ Rålamb was in good standing with the English envoy Thomas Bendish, and this meant that they met both formally and had more mundane interactions. Most likely, knowledge circulation happened in both official meetings and the informal exchange of services and in socialising. As emphasised by Jan Hennings and Tracey Sowerby, a defining feature of early modern diplomatic practices was that they spanned both formalised settings and everyday interactions. ${ }^{73}$

Thomas Bendish lent a significant amount of money to Rålamb. ${ }^{74}$ This is noteworthy since, as discussed by Daniel Goffman, Bendish had had economic difficulties and had attempted to force contributions from English merchants only a few years previously. ${ }^{75}$ There is no evidence that Rålamb himself was engaged in trading ventures, though he did clearly pay to get up-to-date information. ${ }^{76}$ As shown by Michael Talbot, the information networks on which diplomats relied were interlinked with the economic interests of at least some of the actors. ${ }^{77}$ These interests and other personal concerns might align with state policy, but this was not necessarily the case. In such instances, friction could disrupt diplomatic knowledge networks.

For example, while the French ambassador de la Haye frequently acted on Rålamb's behalf during the latter's first month in Istanbul, the relationship soured in June 1657. In his travel journal, Rålamb put down the change to jealousy and anger. He wrote that it was because he [the Frenchman] was angry that I had visited the English [resident] first' one evening. ${ }^{78}$ The altercation may seem petty. Still, from this point onwards, the relationship between Rålamb and de la Haye visibly soured.

72 'Engelendarens Tienare som förde ööl till herren', Hansson, Olof Hanssons kassabok, fol. 20v.

73 Practices of Diplomacy, p. 2.

${ }_{74}$ Hansson, Olof Hanssons kassabok, fol. 27v; Rålamb, Diarium, p. 162.

75 Goffman, Britons, p. 142.

76 Kling, Diarium, fol. 31r; Rålamb, Diarium, p. 174.

77 Talbot, British-Ottoman Relations.

78 'effter han förtröt det iag Engeländaren hade gifwit den första Visiten', Rålamb, Diarium, p. 119. 
This is somewhat surprising since France and Sweden were discussing a military alliance at the time. However, it is clear that Ralamb wanted his reader to perceive de la Haye as actively obstructing his work. With annoyance, Rålamb noted that de la Haye 'against his obligation and recommendation tried the same [the Swedish case] in all possible ways to counteract because of private grievances'.$^{79}$ This highlights an important point: conflicts and miscommunication could be used both during an embassy and after its completion. That the French had worked against him was useful for Rålamb in that it could play a part in explaining his own failure to procure an alliance with Transylvania. Thus, friction in knowledge circulation at one point during a diplomatic mission could be used as an advantage later.

The example also shows that Rålamb himself was aware that personal inclinations influenced the assistance he could expect from the other diplomats. Similarly, in December 1657, Rålamb sent a letter to the other diplomats drawing their attention to what he described as an 'uncivil answer' from an Ottoman official. Rålamb noted that:

The Frenchman [Jean de la Haye] wrote to two of his friends because he was not in good standing with the Grand Vizier [Mehmet Köprulu Paşa], the Englishman [Thomas Bendish] wrote to the Grand Vizier, the Dutchman [Levinus Warner] to no one, he only thought about it. ${ }^{80}$

Rålamb expected that the different interests and personalities of the other diplomats would influence their actions. Similarly, Secretary Kling noted that the other European diplomats were interested in the Swedish cause because they felt they might end up in a similar situation later on. ${ }^{81}$ As we have seen already, this was not an unwarranted assumption.

In the long run, personal risks and potential gains could change. While the political goals of the embassy were not achieved, it most

79 'twärt emot sin Obligation och Recomendation sökte det samma på alle giörliga sätt allenast af et privat picanteri at Contracarera', ibid., p. 145.

80 'Fransosen skref till twenne sine wänner effter han intet stog wäl med Viziren, Engländaren skref till Viziren, Hålländaren till ingen, an tog det allenast I betänckiande’, ibid., p. 173.

81 Kling, Hans Kongl Majtts Ablegation, fol. 150v. 
likely facilitated career mobility for its participants. ${ }^{82}$ After returning from Istanbul, Rålamb had a distinguished career, seen for example in that he reached the noble title Baron, and became a councillor of the realm. ${ }^{83}$ Secretary Kling was ennobled in 1660 and had a distinguished career, among other postings serving as an envoy to Russia. ${ }^{84}$ Welling's secretary Johan Ulrich Wallich was ennobled in 1661, and he continued to serve as a diplomat and in the Swedish administration in Stade. We see here how early modern travel and accounts thereof promoted the traveller's qualifications at home. ${ }^{85}$

Beyond the specific circumstances of this case, we get a sense of the nature of how early modern diplomats collaborated in sharing information. This was not simply a straightforward 'what is yours is mine', nor wholly dependent on the high politics of European states. Instead, personal interests such as monetary gains and friendship could enable collaboration, while at the same time hierarchies and the risk of associating with those whose standing was low created friction in knowledge-sharing networks. Knowledge circulation had a price, both in terms of monetary exchanges, business interests, and for maintaining personal and professional relationships. However, that price could change over time and in relation to different audiences. Similarly, as Kaarle Wirta, Jaakko Björklund and Katja Tikka discuss, the effects of trading ventures could change in a long-term perspective. ${ }^{86}$ As an additional layer, it is worth noting that though the risk might be too high for the individual, it could be warranted for the empire they were serving, thereby complitcating what it meant to be an agent of empire. ${ }^{87}$

82 Gotthard Welling, who came from a German-Baltic noble family, died in 1659, making it difficult to know what effects the journey could have had for him.

${ }^{83}$ Asker, 'Clas Rålamb'.

84 'Klingstedt, släkter', Svenskt biografiskt lexikon, https://sok.riksarkivet.se/Sbl/ Start.aspx (accessed 13 March 2021).

85 Jacob Orrje, Mechanicus: Performing an early modern persona (Uppsala: Acta Universitatis Upsaliensis, 2015); Lisa Hellman, 'Using China at Home: Knowledge Production and Gender in the Swedish East India Company, 1730-1800', Itinerario, 38 no. 1 (Apr. 2014), 35-55.

${ }^{86}$ See Kaarle Wirta, Jaakko Björklund, and Katja Tikka in this issue.

87 See the Introduction to this issue. 


\section{CONCLUSIONS}

This study has examined how Claes Rålamb's ability to act as an agent of the Swedish Empire changed during his embassy to the Ottoman Empire from 1657 to 1658 , and in relation to the reputation of the embassy once it was completed. In particular, the study has applied the perspective of the history of knowledge to highlight how diplomatic agency was connected to situation-specific forms of knowledge. This did not only entail situations of apparent success - like the journey to Istanbul, where Rålamb seems to have possessed the necessary knowledge to subvert the diplomatic persona and travel incognito. Instead, in line with recent interests within the history of knowledge, the present study has paid particular attention to situations where agency broke down and has examined how this was tied to friction within knowledge circulation networks. The need for up to date information needed to be weighed against security concerns and negotiated in relation to the interests of other actors.

Neither knowledge nor agency was, however, static. The case of Rålamb’s embassy shows how access to information had different significance at different stages of a sequence of events. The importance of knowing what was going on was as acute for Rålamb at the outset of a diplomatic mission as it was on the road to Istanbul and during negotiations with the other foreign diplomats and with the Ottomans. However, the framework within which the Swedish legation acted changed between different stages of the journey. This makes the struggle for information a fruitful focal point for examining early modern empire that goes beyond traditional national frameworks and categories of actors. Rålamb was sent out as an envoy of the Swedish Empire, yet the meaning of that position changed constantly.

Thus, though misinformation and miscommunication constituted severe problems in some situations, it was an advantage in others. After all, the accounts that Rålamb and his fellow travellers made were intended for audiences beyond Istanbul. The embassy's accounts include many descriptions of miscommunications and a frustrating lack of information, but at the end of the day, much of this seems to have been intended to present dangerous and challenging situations, thereby emphasising the valour of the Swedish diplomats. In Rålamb's account, many episodes 
have explanations that made his lack of success in procuring an alliance seem less of a personal failure. For Rålamb, then, agency and a lack of success went hand in hand, prompting a reconsideration of the role of information in early modern diplomacy.

\section{BIBLIOGRAPHY}

\section{Archival Sources}

Kungliga biblioteket, Stockholm,

Rål. Fol. 135

Rål. 4:o 25

Rål. 8:o 10

Nordiska Museet, Stockholm,

Granhammarsamlingen

Uppsala University Library, Uppsala,

N 439

Riksarkivet, Stockholm,

Turcica I. Svenska beskickningar till Turkiet brev och arkiv, vol. 3

\section{Printed primary sources}

Hiltebrandt, Conrad Jacob, Conrad Jacob Hiltebrandt's Dreifache Schwedische Gesandtschaftsreise nach Siebenbürgen, der Ukraine und Constantinopel (1656-1658), ed. by Franz Babinger (Leiden: Brill, 1937)

Rålamb, Claes, Diarium under resa till Konstantinopel 1657-1658, ed. by Christian Callmeri, Historiska Handlingar Series, 37:3 (Stockholm: Kungl. Samfundet för utgifvande af handskrifter rörande Skandinaviens historia, 1963) Kort beskriffning om thet som wid then Constantinopolitaniske resan är foreluppit (Stockholm, 1679)

Rålamb, Nicholas, 'A relation of a journey to Constantinople', in $A$ collection of voyages and travels, some now first printed from original manuscripts, others now first published in English (London, 1732)

Wallich, Johann Ulrich, Religio Turcica (Stade: Typis Holvinianis, 1659)

\section{Secondary Works}

Ådahl, Karin (ed.), The Sultan's Procession: The Swedish Embassy to Sultan Mehmed IV in 1657-1658 (Istanbul: Swedish Research Institute in Istanbul, 2006) 
Alm, Mikael (ed.), Performing Herself: Everyday Practices and the Making of Gender in Early Modern Sweden (Uppsala: Uppsala University, 2017)

Bisaha, Nancy, Creating East and West: Renaissance Humanists and the Ottoman Turks (Philadelphia: University of Pennsylvania Press, 2004)

Brendemoen, Bernt, 'Some Remarks on Claes Brodersson Rålamb and his contemporaries', in Turcica et Orientalia, vol. 1: Studies in honour of Gunnar Jarring on his eightieth birthday 12 October 1987 (Stockholm: Swedish Research Institute in İstanbul, 1988)

Bäärnhielm, Göran, 'Orientalistiken i Sverige fram till 1720-talet', in En resenär i svenska stormaktstidens språklandskap: Gustaf Peringer Lillieblad (1651-1710), ed. by Éva Á. Csató, Gren-Eklund Gunilla, and Folke Sandgren (Uppsala: Acta Universitatis Upsaliensis, 2007)

Cevrioğlu, Mahmut Halef, 'Grand vizierial reception ceremonies of European ambassadors in the first half of the seventeenth century', Legatio, 4 (2020)

Cornago, Noé, 'Diplomatic knowledge', in The SAGE handbook in diplomacy, ed. by Costas M. Constantinou, Pauline Kerr and Paul Sharp (London: SAGE Publications Ltd., 2016)

'Making decisions at the imperial court in Vienna related to the election procedure of the resident ambassador Simon Reniger von Renningen (1649-1666) in Constantinopel', Archivum Ottomanicum, 33 (2016)

Cziráki, Zsuzsanna, 'Language students and interpreters at the mid-seventeenthcentury Habsburg embassy in Constantinopel', Theatrum Historiae, 19 (2016)

De Vivo, Filippo, 'Archives of speech: recording diplomatic negotiation in late medieval and early modern Italy', European History Quarterly, 46, no. 3 (2016)

Ettlinger, Kaj M., 'Aslan Aga - turkisk ambassadör till Sverige eller svenskt sändebud med diplomatiska uppdrag till Turkiet?', Personhistorisk tidskrift, 94 (1998)

Florén, Anders, and Åsa Karlsson (eds), Främlingar: Ett historiskt perspektiv (Uppsala: Historiska institutionen, Uppsala Univiversitet, 1998)

Forss, Charlotta, The Old, the New and the Unknown: The Continents and the Making of Geographical Knowledge in Seventeenth-Century Sweden (Turku: Iloinen tiede, 2018)

Goffman, Daniel, Britons in the Ottoman Empire, 1642-1660 (Seattle-London: University of Washington Press, 1998)

Gürkan, Emrah Safa, 'Mediating boundaries: Mediterranean go-betweens and crossconfessional diplomacy in Constantinople, 1650-1600', Journal of Early Modern History, 19, nos. 2-3 (2015)

Hay, Denys, Europe: The Emergence of an Idea (Edinburgh: Harper Torchbooks, 1966) Hellman, Lisa, 'Using China at Home: Knowledge Production and Gender in the Swedish East India Company, 1730-1800', Itinerario, 38, no. 1 (Apr. 2014)

Hennings, Jan, 'Information and Confusion: Russian Resident Diplomacy and Peter A. Tolstoi's Arrival in the Ottoman Empire (1702-1703)', International History Review, 41, no. 5 (2019) , and Tracey Sowerby, 'Introduction' in Practices of Diplomacy in the Early Modern World c. 1410-1800, ed. by Jan Hennings and Tracey Sowerby (London: Routledge, 2017) 
Hossain, Mary, 'The employment and training of interpreters in Arabic and Turkish under Louis XIV: France', Seventeenth-Century French Studies, 14, no. 1 (1992)

Işıksel, Güneş, 'Hierarchy and Friendship: Ottoman Practices of Diplomatic Culture and Communication (1290s-1600)', Medieval History Journal, 22, no. 2 (2019)

, 'Ottoman Diplomacy', in The Encyclopedia of Diplomacy, ed. by Gordon Martel (Chichester, John Wiley \& Sons, 2018)

Kárman, Gábor, 'Främlingskapets grader: Claes Rålambs resa till Osmanska riket 1657-1658', Karolinska forbundets årsbok (2008)

, 'The networks of a Wallachian pretender in Constantinople: the contacts of the future voivode Mihail Radu 1654-1657', in Europe and the 'Ottoman World': Exchanges and Conflicts (Sixteenth to Seventeenth Centuries), ed. by Gábor Kármán and Radu G. Paun (Istanbul: The Isis Press, 2013)

Confession and Politics in the Principality of Transylvania 1644-1657 (Göttingen: Vandenhoeck \& Ruprecht, 2020)

Kolçak, Özgür, 'A Transylvanian ruler in the talons of the 'hawks': György Rákóczi II and Köprülü Mehmed Pasha', in Turkey \& Romania: A History of Partnership and Collaboration in the Balkans, ed. by Florentina Nitu et al. (Istanbul: Union of Turkish World Municipalities, 2016)

Kołodziejczyk, Dariusz, 'Semiotics of behavior in early modern diplomacy: Polish embassies in Istanbul and Bahçesaray', Journal of Early Modern History, 7, nos. 3-4 (2003)

Larsson, Göran, 'En svensk 1600-talsbeskrivning från den Stora Porten i öster', Folkets historia, 27, no. 2 (1999)

Lidström, Carina, Berättare på resa: Svenska resenärers reseberättelser 1667-1829 (Stockholm: Carlssons förlag, 2015)

Orrje, Jacob, Mechanicus: Performing an early modern persona (Uppsala: Acta Universitatis Upsaliensis, 2015)

Östling, Johan, Erling Sandmo, David Larsson Heidenblad, Anna Nilsson Hammar and Kari Nordberg (eds), Circulation of Knowledge: Explorations in the History of Knowledge (Lund: Nordic Academic Press, 2018)

Pajur, Astrid, Dress Matters: Clothes and Social Order in Tallinn, 1600-1700 (Uppsala: Acta Universitatis Upsaliensis, 2020)

Proctor, Robert and Londa Schiebinger (eds), Agnotology: The Making and Unmaking of Ignorance (Stanford: Stanford University Press, 2008)

Raj, Kapil, Relocating Modern Science: Circulation and the Construction of Knowledge in South Asia and Europe, 1650-1900 (New York: Palgrave Macmillan, 2007)

Rothman E. Natalie, 'Interpreting dragomans: boundaries and crossings in the early monder Mediterranean' Comparative Studies in Society and History 51, 4 (2009) Brokering Empire: Trans-Imperial Subjects between Venice and Istanbul (Ithaca: Cornell University Press, 2011)

Rouillard, Clarence Dana, The Turk in French History, Thought, and Literature (1520-1660), Etudes de Litterature Etrangere et compare Series, no. 13 (Paris: Boivin \& Cie, 1940) 
Rublack, Ulinka, Dressing Up: Cultural Identity in Renaissance Europe (Oxford: Oxford University Press 2010)

Secord, James A., 'Knowledge in Transit', Isis, 95, no. 4 (2004)

Shapin, Steven, and Simon Schaffer, Leviathan and the Air-Pump: Hobbes, Boyle, and the Experimental Life (Princeton: Princeton University Press, 1985)

Sternberg, Giora, 'Epistolary ceremonial: corresponding status at the time of Louis XIV', Past and Present, 204 (2009)

Święcicka, Elżbieta, 'Den diplomatiska trafiken mellan Sverige, Tartariet och Osmanska riket från Gustav Vasas tid till Karl XII', in Den nordiska mosaiken: Språk- och kulturmöten i gammal tid och i vaira dagar, humanistdagarna vid Uppsala universitet 1997, ed. by Rut Boström Andersson (Uppsala, 1997)

, 'Ottoman manuscripts in Europe: the collection of Ottoman-Turkish documents in Sweden', in Frontiers of Ottoman Studies: State, province, and the west, ed. by Colin Imber, Keiko Kiyotaki and Rhodas Murphey (London: I.B. Tauris, 2005)

Talbot, Michael, British-Ottoman Relations, 1661-1807: Commerce and Diplomatic Practice in Eighteenth-Century Istanbul (Woodbridge: The Boydell Press, 2017)

Verburgt, Lukas M., 'The history of knowledge and the future history of ignorance', KNOW, 4 (2020)

Vogel, Christine, 'The Caftan and the Sword: Dress and Diplomacy in Ottoman-French Relations Around 1700', in Fashioning the Self in Transcultural Settings: The Uses and Significance of Dress in Self-Narratives, ed. by Claudia Ulbrich and Richard Wittmann (Würzburg: Ergon Verlag, 2015)

White, Jason Cameron, 'Royal authority versus corporate sovereignty: the Levant Company and the ambiguities of early Stuart statecraft', Seventeenth Century, 32, no. 3 (2017)

Wirta, Kaarle, Early Modern Overseas Trade and Entrepreneurship (London: Routledge, 2020)

Withington, Phil, 'Company and sociability in early modern England', Social History, 32, no. 3 (2007)

Zwierlein, Cornel (ed.), The Dark Side of Knowledge: Histories of Ignorance, 1400 to 1800 (Leiden: Brill, 2016)

\section{Online Publications}

Asker, Björn, 'Clas Rålamb', Svenskt biografiskt lexikon, https://sok.riksarkivet.se/Sbl/ Start.aspx (accessed 13 March 2021)

'Klingstedt, släkter', Svenskt biografiskt lexikon, https://sok.riksarkivet.se/Sbl/Start.aspx (accessed 13 March 2021)

Saunders, Liane, 'Bendish', in Oxford Dictionary of National Biography, https://www. oxforddnb.com (accessed 5 June 2021) 
Charlotta Forss $(\mathrm{PhD})$ - researcher at the Department of History, Stockholm University. In 2021-22, guest researcher at University of Oxford, Oriel College. Her research interests focus on the intersection between early modern history of science and cultural and social history; e-mail: charlotta.forss@historia.su.se 